\title{
REGIONAL AND SOCIODEMOGRAPHIC DETERMINANTS OF THE PREVALENCE OF OVERWEIGHT AND OBESITY IN CHILDREN AGED 7-9 YEARS IN CROATIA
}

\author{
Sanja Musić Milanovići, ${ }^{1,2}$ Maja Lang Morović ${ }^{1}$, Dora Bukal ${ }^{1}$, Helena Križan ${ }^{1}$, \\ Marta Buoncristiano ${ }^{3}$ and João Breda ${ }^{3}$
}

\author{
${ }^{1}$ Health Promotion Division, Croatian Institute of Public Health, Zagreb, Croatia; \\ ${ }^{2}$ Andrija Štampar School of Public Health, School of Medicine, University of Zagreb, Zagreb, Croatia; \\ ${ }^{3}$ European Office for Prevention and Control of Noncommunicable Diseases, \\ World Health Organization, Moscow, Russia
}

\begin{abstract}
SUMMARY - The aim of this study was to determine the prevalence and analyze the determinants of overweight and obesity among Croatian schoolchildren aged 7-9 years in relation to sociodemographic factors. This study used data that were gathered as part of the WHO Europe Childhood Obesity Surveillance Initiative in 2015/2016. The sample for the study was nationally representative. Anthropometric measurements of 5591 children, 2811 boys and 2780 girls, were collected during 8 weeks using standardized equipment. Studied variables included child's anthropometric measurements and demographics, maternal education and employment status. The results showed a $35.9 \%$ prevalence of overweight and obesity in Croatian 7-9-year-old children. Overweight and obesity were more frequent in boys in comparison to girls, especially among boys from the Adriatic region (42.1\%). The risk of overweight and obesity was increased in boys living in the Adriatic region (ORadj=1.33; 95\% CI 1.03-1.71) and in girls with high-school educated mothers (ORadj=1.36; 95\% CI 1.11-1.66). Girls with unemployed mothers had a lower risk of overweight and obesity (ORadj=0.73; 95\% CI 0.58-0.92). The observed prevalence of childhood overweight and obesity warrants national and local time-bound targets for reduction of childhood obesity, accompanied by detailed action plans and monitoring mechanisms.
\end{abstract}

Key words: Prevalence; Overweight; Obesity; Children; Croatia

\section{Introduction}

Childhood overweight and obesity represents a serious challenge as a global public health problem. Children with overweight or obesity are more probable to stay obese later in life, and they are at a greater risk of developing noncommunicable diseases ${ }^{1}$. According to the World Health Organization (WHO),

Correspondence to: Dora Bukal, Health Promotion Division, Croatian Institute of Public Health, Rockefellerova 7, HR-10000 Zagreb, Croatia

E-mail: dora.bukal@hzjz.hr

Received April 21, 2020, accepted May 19, 2020 in 2016, globally there were over 340 million overweight or obese children aged $5-19^{2}$. Data from the World Health Organization Regional Office for Europe (WHO/Europe), Childhood Obesity Surveillance Initiative (COSI) showed that the prevalence of overweight or obesity in children aged 6-9 years in 2015-2017 in Europe varied from 18\% in Denmark to $43 \%$ in Cyprus for boys and from $16 \%$ in Albania to $43 \%$ in Cyprus for girls ${ }^{3}$.

Childhood obesity is greatly influenced by sociodemographic factors. In Europe, a north-south gradient is observed with a higher prevalence of childhood overweight and obesity in southern Europe ${ }^{4,5}$. Studies 
on formal parental education and urbanization seem to have converse findings, which appears to be linked to the level of country development ${ }^{6,7}$. Specifically, maternal education was negatively associated with childhood obesity in several studies showing that overweight and obesity risk was greater among children whose mothers had lower education ${ }^{8}$.

In order to better understand the magnitude of this problem, it is crucial to have a well-developed system for childhood obesity surveillance, tracking and prevention'. In 2006, WHO/Europe and 13 Member States introduced the COSI survey, targeting children aged 6-9 years ${ }^{10}$. Croatia joined this surveillance initiative in the fourth round in 2015/2016.

The aim of this study was to identify the prevalence of overweight and obesity among Croatian schoolchildren aged 7.0-9.9 years in relation to sociodemographic factors such as age, sex, geographical region of living, level of urbanization, maternal formal education level and employment status.

\section{Methods}

\section{Material}

In order to organize standard measurements of body weight and height in schoolchildren in Europe, $\mathrm{WHO} /$ Europe has established a coordinated surveillance system, COSI. The goal of COSI is to collect Europe-wide comparable data regarding anthropometric measurement of children including body height, weight and waist and hip circumference in order to record and monitor nutritional status in children aged 6.0-9.9 years. This research was planned as semi-longitudinal with repetitions at certain periods in time ${ }^{10}$. The research was implemented in accordance with the COSI Protocol ${ }^{11}$.

\section{Methods}

Sampling was conducted at the national level. A cluster sample design with elementary school classes as sampling units was used. The sampling frame consisted of 32626 students from 1707 second-grade classes of 878 elementary schools. A simple random sample of second-grade classes was taken using the STATISTICA program. As a result, 182 second-grade classes were included in this research. Third-grade classes were chosen to match second-grade classes from the same schools. Out of 7150 students from 164 chosen schools, a total of 5662 children aged 6 to 11 years took part in the measurement, with a response rate $79.2 \%$. Children who were not measured did not have parental consent, were absent from school or actively declined to undergo measurement. This paper uses data only on children aged 7.0 to 9.9 years $(\mathrm{N}=5591)$.

Data were collected during fieldwork, which lasted from October to December 2015. Children were measured by two-member teams trained in taking standardized measurements according to the protoco ${ }^{11}$. In total, 26 examiners worked on data collection. Children's body weight and height were measured using 22 sets of weight scales (SECA 877, SECA, Hamburg, Germany) and stadiometers (SECA 217, SECA, Hamburg, Germany). Scales were calibrated by the manufacturer. Weight was measured in kilograms and recorded to the nearest $0.1 \mathrm{~kg}$. Height was measured in centimeters and the reading taken to the last completed $0.1 \mathrm{~cm}$. For accuracy, the height was measured twice and the mean value of two measurements was used for analysis. Additional data on sociodemographic characteristics of the children were obtained from a family form the parents were asked to fill in. The original data-collection forms, created by the WHO, were used and translated into Croatian.

\section{Ethics}

The research was conducted in accordance with the ethical principles of autonomy, beneficence and nonmaleficence, and in accordance with the WHO COSI Protocol $^{11}$. The Ethics Committee of the Croatian Institute of Public Health approved this research in July 2015 (no: 602-01/15-01/0242). A consent form had to be signed by the child's parents or custodians in order to obtain the child's anthropometric measures. However, right before the measurement, the child was asked once again for the active consent to participate in the study.

\section{Variables}

Data on children's demographics included child's sex, age, geographical region and level of urbanization. Children's age ranged from 7.0 to 9.9 (mean 8.62) years. Geographical regions were selected according to the NUTS 2 criteria $^{12}$. Additionally, based on a study previously conducted in Croatia ${ }^{13}$, the City of Zagreb 


\section{Table 1. Selected characteristics}

\begin{tabular}{|l|l|}
\hline Variable & \\
\hline Age (years; mean \pm SD) & $8.62 \pm 0.6$ \\
Height $(\mathrm{cm} ;$ mean \pm SD) & $135.5 \pm 6.8$ \\
Weight $(\mathrm{kg} ;$ mean $\pm \mathrm{SD})$ & $32.6 \pm 7.7$ \\
Body mass index $\left(\mathrm{kg} / \mathrm{m}^{2} ;\right.$ mean $\left.\pm \mathrm{SD}\right)$ & $17.6 \pm 3.1$ \\
\hline Sex: $\mathbf{n}(\%)$ & \\
Girls & $2780(49.7)$ \\
Boys & $2811(50.3)$ \\
\hline Age group (years): $\mathbf{( \% )}$ & \\
7.0-7.9 & $960(17.2)$ \\
8.0-8.9 & $2733(48.9)$ \\
9.0-9.9 & $1898(33.9)$ \\
\hline Geographical region of living*: $\mathbf{n}(\%)$ & \\
Continental & $2773(49.6)$ \\
Adriatic & $1784(31.9)$ \\
City of Zagreb & $1034(18.5)$ \\
\hline Level of urbanization: $\mathbf{n}(\%)$ & $3202(57.3)$ \\
Urban & $1691(30.2)$ \\
Semi-urban & $695(12.4)$ \\
Rural & $3(0.1)$ \\
Missing & \\
\hline Maternal educational level: $\mathbf{n}(\%)$ & $328(5.9)$ \\
Elementary school & $2790(49.9)$ \\
High school & $1505(26.9)$ \\
College degree or higher & $968(17.3)$ \\
Missing & $1092(19.5)$ \\
\hline Maternal employment status: $\mathbf{n}(\%)$ & $3503(62.7)$ \\
Unemployed $\dagger$ & $996(17.8)$ \\
Employed & \\
Missing & \\
\hline
\end{tabular}

$\mathrm{SD}=$ standard deviation; all results were obtained through weighted analysis; "geographical regions based on NUTS 2 classification, classified as continental and Adriatic region. The City of Zagreb was excluded from the continental region and considered as a separate region because of cultural and traditional differences; $†$ the category 'unemployed' includes persons that were unemployed, homemakers, students, retirees and unemployed people unable to work.

was observed as a separate region because as a capital it is also a melting pot in Croatia and is expected to incorporate features of both the continental and Adriatic regions. Level of urbanization of the child's place of living was determined in accordance with the Croatian Bureau of Statistics ${ }^{14}$, and was described as urban, semi-urban and rural.
Body mass index (BMI) was calculated as weight in kilograms divided by height in square meters. In this study, overweight and obesity were defined by and presented using the set of cut-off points published by the $\mathrm{WHO}^{15}$. Socioeconomic status of the family was analyzed via two variables from the family form, i.e. completed level of maternal formal education and maternal employment status. The family form was filled in by the mother of the child in most cases (83.3\%). Only those cases in which the mother was the one giving information on herself were included in the analysis.

\section{Statistical analysis}

All statistical analyses were performed using the SPSS Statistics 21.0 statistical package (IBM Corporation, Chicago, IL, USA). The level of significance was set at $\mathrm{p}<0.05$. Weights to adjust for the sampling design, oversampling and non-response were calculated and used to infer the results from the sample to the population.

First, prevalence rates and descriptive statistics for investigated variables were calculated. Differences in the prevalence of overweight and obesity between the groups based on sex and geographical region were tested with Pearson $\chi 2$.

Adjusted odds ratios (ORs) of being overweight or obese were estimated by carrying out a binary logistic regression analysis: a logistic model including the above-mentioned variables as covariates was estimated for boys and girls separately and for all children together.

\section{Results}

The study sample consisted of 5591 children aged 7.0 to 9.9 years, 2811 boys and 2780 girls (Table 1). Data on children's nutritional status according to the WHO criteria are presented in Table 2. These data show that there was $1 \%$ of thin children. More than one-third of children (35.9\%) were overweight or obese. There was a significant difference in nutritional status between boys and girls $\left(\chi^{2}=74.236, p<0.001\right)$. Obesity, including severe obesity, was more prevalent among boys in comparison to girls (18.4\% vs. $10.8 \%)$; the more so, $5.3 \%$ of boys could be classified as severely obese.

When looking at different geographical regions (Table 3), there was a statistically significant difference 
Table 2. Nutritional status of children according to WHO criteria

\begin{tabular}{|l|l|l|l|l|l|}
\hline \multirow{2}{*}{ WHO criteria } & Thinness & Recommended weight & Overweight & Obesity & Severe obesity \\
\cline { 2 - 6 } & $\%$ & $\%$ & $\%$ & $\%$ & $\%$ \\
\hline Boys & 0.6 & 60.0 & 21.1 & 13.1 & 5.3 \\
Girls & 1.3 & 66.4 & 21.5 & 9.2 & 1.6 \\
Total & 1.0 & 63.1 & 21.3 & 11.1 & 3.5 \\
\hline
\end{tabular}

Prevalence estimates were based on $2007 \mathrm{WHO}$ recommended criteria ${ }^{15}$.

Table 3. Prevalence of overweight and obesity in 3 geographical regions of Croatia

\begin{tabular}{|l|l|l|}
\hline Adriatic region & Overweight (\%) & Obesity (\%) \\
\hline Boys & 23.2 & 18.9 \\
Girls & 22.7 & 9.4 \\
Total & 22.9 & 14.1 \\
\cline { 2 - 3 } & \multicolumn{2}{|c|}{$\chi^{2}=18.296^{*}, \mathrm{p}<0.001$} \\
\hline Continental region & Overweight (\%) & Obesity (\%) \\
\hline Boys & 19.9 & 20.1 \\
Girls & 20.3 & 13.1 \\
Total & 20.1 & 16.6 \\
\cline { 2 - 3 } & \multicolumn{2}{|c|}{$\chi^{2}=11.853^{*}, \mathrm{p}=0.001$} \\
\hline City of Zagreb & Overweight (\%) & Obesity (\%) \\
\hline Boys & 20.6 & 14.1 \\
Girls & 22.4 & 7.3 \\
Total & 21.5 & 10.8 \\
\cline { 2 - 3 } & \multicolumn{2}{|c|}{$\chi^{2}=2.454^{*}, \mathrm{p}=0.117$} \\
\hline
\end{tabular}

*Continuity correction for $2 \times 2$ table.

in the prevalence of overweight and obesity $\left(\chi^{2}=7.313\right.$, $\mathrm{p}=0.026$ ). The highest prevalence of overweight and obesity was found in the Adriatic region (37\%), followed by the continental region (36.7\%), and the lowest prevalence was observed in the City of Zagreb (32.3\%). In the Adriatic region, boys had a significantly higher prevalence of overweight and obesity than girls (42.1\% vs. 32.1\%). The same could be observed in the continental region, where $40 \%$ of boys and $33.4 \%$ of girls were overweight or obese. In the City of $\mathrm{Za}^{-}$ greb, there was no statistically significant difference in the prevalence of overweight and obesity between boys and girls.

The predictive value of geographical region, level of urbanization, maternal education level and maternal employment status was tested using binomial logistic regression and the results are shown in Table 4 . When adjusted for other investigated variables, geographical region, maternal education level and maternal employment status were significant predictors of childhood overweight and obesity. Children living outside the City of Zagreb had a greater chance of overweight and obesity (OR $=1.21 ; 95 \%$ CI 1.00-1.45) than children living in Zagreb. Children of high school educated mothers had a greater chance for overweight and obesity (OR=1.24; 95\% CI 1.08-1.42) than those of mothers with higher education level. In addition, children of unemployed mothers had a $20 \%$ lower chance for overweight and obesity (OR=0.80; 95\% CI 0.69-0.93) than those with employed mothers. When stratified by sex, living in the Adriatic region was the only statistically significant predictor for overweight and obesity in boys after adjusting for confounders. Boys from the Adriatic region had a greater chance for being overweight and obese (OR=1.33; 95\% CI 1.03-1.71) than boys from Zagreb. Statistically significant predictors of overweight and obesity for girls, after adjusting for confounders, were maternal education level and maternal employment status. Girls with high school educated mothers had higher odds for being overweight or obese $(\mathrm{OR}=1.36$; 95\% CI 1.11-1.66) than girls with college or higher educated mothers. In addition, girls with unemployed mothers had lower odds for being overweight or obese (OR=0.73; 95\% CI 0.58-0.92) than girls with employed mothers. After adjustment, urbanization itself was not a statistically significant predictor of overweight and obesity in children.

\section{Discussion}

Our study, aiming to determine the prevalence of overweight and obesity in 7-9-year-old children showed an overall high prevalence of overweight and obesity in Croatian children, positioning Croatia among the Mediterranean countries like Malta, $\mathrm{Cy}$ - 
Table 4. Association of geographical region, level of urbanization and maternal socioeconomic status with overweight and obesity among 7-9-year-old Croatian children* $\dagger$

\begin{tabular}{|c|c|c|c|c|c|c|}
\hline & \multicolumn{2}{|c|}{ Boys } & \multicolumn{2}{|c|}{ Girls } & \multicolumn{2}{|c|}{ Total } \\
\hline & \begin{tabular}{|l|} 
OR \\
$(95 \% \mathrm{CI})$
\end{tabular} & $\begin{array}{l}\mathrm{OR}_{\mathrm{adj}} \\
(95 \% \mathrm{CI})\end{array}$ & $\begin{array}{l}\text { OR } \\
(95 \% \mathrm{CI})\end{array}$ & $\begin{array}{l}\mathrm{OR}_{\text {adj }} \\
(95 \% \mathrm{CI})\end{array}$ & $\begin{array}{l}\text { OR } \\
(95 \% \mathrm{CI})\end{array}$ & $\begin{array}{l}\mathrm{OR}_{\mathrm{adj}} \\
(95 \% \mathrm{CI})\end{array}$ \\
\hline \multicolumn{7}{|c|}{ Geographical region $\neq \S$} \\
\hline City of Zagreb & 1.0 (Ref) & 1.0 (Ref) & 1.0 (Ref) & 1.0 (Ref) & 1.0 (Ref) & 1.0 (Ref) \\
\hline Continental & $\begin{array}{l}1.25 \\
(1.02-1.54) \\
p=0.033\end{array}$ & $\begin{array}{l}1.21 \\
(0.94-1.55) \\
p=0.129\end{array}$ & $\begin{array}{l}1.18 \\
(0.95-1.48) \\
p=0.138\end{array}$ & $\begin{array}{l}1.19 \\
(0.91-1.56) \\
p=0.202\end{array}$ & $\begin{array}{l}1.21 \\
(1.04-1.41) \\
\mathrm{p}=\mathbf{0 . 0 1 2}\end{array}$ & $\begin{array}{l}1.21 \\
(1.00-1.45) \\
\mathrm{p}=\mathbf{0 . 0 4 4}\end{array}$ \\
\hline Adriatic & $\begin{array}{l}1.37 \\
(1.10-1.71) \\
p=0.006\end{array}$ & $\begin{array}{l}1.33 \\
(1.03-1.71) \\
\mathrm{p}=\mathbf{0 . 0 2 8}\end{array}$ & $\begin{array}{l}1.11 \\
(0.88-1.41) \\
p=0.375\end{array}$ & $\begin{array}{l}1.08 \\
(0.82-1.42) \\
p=0.583\end{array}$ & $\begin{array}{l}1.23 \\
(1.05-1.45) \\
p=0.012\end{array}$ & $\begin{array}{l}1.21 \\
(1.00-1.46) \\
\mathrm{p}=\mathbf{0 . 0 4 5}\end{array}$ \\
\hline \multicolumn{7}{|c|}{ Level of urbanizationII } \\
\hline Rural & 1.0 (Ref) & 1.0 (Ref) & 1.0 (Ref) & 1.0 (Ref) & 1.0 (Ref) & 1.0 (Ref) \\
\hline Urban & $\begin{array}{l}1.00 \\
(0.79-1.27) \\
p=0.993\end{array}$ & $\begin{array}{l}1.01 \\
(0.76-1.34) \\
p=0.935\end{array}$ & $\begin{array}{l}0.76 \\
(0.59-0.97) \\
\mathrm{p}=\mathbf{0 . 0 2 8}\end{array}$ & $\begin{array}{l}0.79 \\
(0.60-1.06) \\
p=0.116\end{array}$ & $\begin{array}{l}0.88 \\
(0.74-1.04) \\
p=0.127\end{array}$ & $\begin{array}{l}0.89 \\
(0.73-1.09) \\
\mathrm{p}=0.259\end{array}$ \\
\hline Semi-urban & $\begin{array}{l}1.19 \\
(0.92-1.53) \\
p=0.185\end{array}$ & $\begin{array}{l}1.12 \\
(0.84-1.49) \\
p=0.434\end{array}$ & $\begin{array}{l}0.78 \\
(0.60-1.01) \\
p=0.060\end{array}$ & $\begin{array}{l}0.81 \\
(0.61-1.09) \\
p=0.163\end{array}$ & $\begin{array}{l}0.96 \\
(0.80-1.16) \\
p=0.686\end{array}$ & $\begin{array}{l}0.95 \\
(0.77-1.16) \\
p=0.616\end{array}$ \\
\hline \multicolumn{7}{|c|}{ Maternal education level 9} \\
\hline $\begin{array}{l}\text { College degree or } \\
\text { higher }\end{array}$ & 1.0 (Ref) & 1.0 (Ref) & 1.0 (Ref) & 1.0 (Ref) & 1.0 (Ref) & 1.0 (Ref) \\
\hline High school & $\begin{array}{l}1.13 \\
(0.94-1.36) \\
p=0.186\end{array}$ & $\begin{array}{l}1.13 \\
(0.93-1.37) \\
p=0.202\end{array}$ & $\begin{array}{l}1.32 \\
(1.09-1.60) \\
p=0.004\end{array}$ & $\begin{array}{l}1.36 \\
(1.11-1.66) \\
p=0.003\end{array}$ & $\begin{array}{l}1.22 \\
(1.07-1.39) \\
p=0.004\end{array}$ & $\begin{array}{l}1.24 \\
(1.08-1.42) \\
\mathrm{p}=\mathbf{0 . 0 0 3}\end{array}$ \\
\hline Elementary school & $\begin{array}{l}0.84 \\
(0.60-1.18) \\
p=0.328\end{array}$ & $\begin{array}{l}0.84 \\
(0.58-1.23) \\
p=0.383\end{array}$ & $\begin{array}{l}1.01 \\
(0.69-1.50) \\
p=0.941\end{array}$ & $\begin{array}{l}1.08 \\
(0.71-1.66) \\
p=0.710\end{array}$ & $\begin{array}{l}0.93 \\
(0.72-1.20) \\
p=0.595\end{array}$ & $\begin{array}{l}0.94 \\
(0.71-1.25) \\
p=0.685\end{array}$ \\
\hline \multicolumn{7}{|c|}{ Maternal employment status** } \\
\hline Employed & 1.0 (Ref) & $1.0(\operatorname{Ref})$ & 1.0 (Ref) & 1.0 (Ref) & 1.0 (Ref) & $1.0(\operatorname{Ref})$ \\
\hline Unemployed $\dagger \dagger$ & $\begin{array}{l}0.86 \\
(0.71-1.05) \\
p=0.146\end{array}$ & $\begin{array}{l}0.87 \\
(0.70-1.07) \\
p=0.195\end{array}$ & $\begin{array}{l}0.80 \\
(0.65-0.99) \\
\mathrm{p}=\mathbf{0 . 0 3 7}\end{array}$ & $\begin{array}{l}0.73 \\
(0.58-0.92) \\
p=0.007\end{array}$ & $\begin{array}{l}0.84 \\
(0.72-0.96) \\
p=0.014\end{array}$ & $\begin{array}{l}0.80 \\
(0.69-0.93) \\
p=0.005\end{array}$ \\
\hline
\end{tabular}

$\mathrm{CI}=$ confidence interval; $\mathrm{OR}=$ odds ratio; $\mathrm{OR}_{\text {adj }}=$ adjusted odds ratio; ${ }^{*}$ prevalence estimates were based on $2007 \mathrm{WHO}$ recommended criteria $^{15}$; †overweight and obese children were compared to all other children; łgeographical regions based on NUTS 2 classification, classified as continental and Adriatic region. The City of Zagreb was excluded from the continental region and considered as a separate region because of cultural and traditional differences; §adjusted for age, (sex), level of urbanization, maternal education and maternal employment; IIadjusted for age, (sex), geographical region, maternal education and maternal employment; $\uparrow$ adjusted for age, (sex), geographical region, level of urbanization and maternal employment; **adjusted for age, (sex), geographical region, level of urbanization and maternal education; †t the category 'unemployed' includes persons that are unemployed, homemakers, students, retirees and unemployed people unable to work.

prus and Greece that have the highest prevalence of childhood overweight and obesity in Europe ${ }^{3}$. The prevalence of childhood overweight and obesity in Europe varies greatly, but one of the most important recent findings is the very high prevalence in south
European countries positioned in the Mediterranean region $^{3,4,16,17}$. While at first, this finding seems unexpected because the traditional Mediterranean diet has long been lauded as one of the healthiest and most balanced ones, there are some explanations for this 
phenomenon. Some authors explain that a big dietary change from the Mediterranean to the Western type of diet has occurred in this $\operatorname{area}^{18}$, and it has been observed that children living in the Mediterranean are less physically active in comparison to children in other European regions ${ }^{19}$. The results of this study have confirmed that Croatia, like other Mediterranean countries, has a great public health challenge ahead and that coordinated regional action is required.

The results of this study showed that there were differences in the prevalence of overweight and obesity according to gender and geographical region. According to our findings, the problem of overweight and obesity was more frequent in boys in comparison to girls (39.5\% and $32.3 \%$, respectively). Especially concerning is the prevalence of severe obesity in boys, as the highest ends of obesity impose the highest risk for both immediate and long-term health ${ }^{20-22}$. The finding that Croatian boys had higher prevalence rates of overweight and obesity than girls, according to the WHO criteria, is in line with previous research conducted in European and non-European countries ${ }^{16,17,23,24}$ and once again confirms that special attention should be paid to health promotion activities for boys.

When observing Croatia as a country composed of three distinct geographical regions, continental, Adriatic and the City of Zagreb, we found that the highest prevalence of overweight and obesity was in the Adriatic region and lowest in the City of Zagreb. In both the Adriatic and continental regions, boys were significantly more frequently overweight or obese than girls. Especially of note is the staggering result of overweight and obesity among boys in the Adriatic region, followed by boys in the continental region and the City of Zagreb. Even when placed in the context of the recently reported high prevalence rates in other Mediterranean countries, this is still an alarmingly high number, only surpassed by the prevalence in boys in Cyprus $^{3}$. This finding might be explained by the fact that the Adriatic region is culturally very similar to other Mediterranean countries, especially in regards to dietary habits, implying that boys living in the coastal areas are becoming less likely to consume the Mediterranean diet ${ }^{25-27}$. What this finding also shows is that the north-south gradient of childhood obesity observed in Europe, where the south has a higher prevalence than the north ${ }^{28}$, can also be observed at the level of a single country with diverse regions, such as Croatia.

Moreover, we explored the possible predictors of childhood overweight and obesity and identified geographical region, maternal education level and maternal employment status as statistically significant predictors. Children living outside the City of Zagreb, both in the continental and Adriatic regions, had higher odds for being overweight or obese than those living in Zagreb. This could be explained by the social gradient of childhood obesity, by which the occurrence of obesity is negatively associated with higher socioeconomic position ${ }^{29-31}$. It is therefore expected for the City of Zagreb, as the Croatian capital and the most inhabited city with the highest level of employment and highest proportion of residents with the highest levels of education ${ }^{32,33}$ to have the smallest proportion of overweight and obese children. When we stratified them by sex, we observed that, specifically, boys living in the Adriatic region had higher odds for overweight and obesity than boys living in Zagreb, which once again confirms the previously discussed findings about the Mediterranean being a risk factor for childhood overweight and obesity, especially in boys.

Parental education seems to be of particular importance regarding childhood overweight and obesity ${ }^{34}$. Specifically, studies suggest that overweight and obesity is more common in children of less educated mothers ${ }^{8,35}$. Our study found that being a child of a mother with high school education bore significantly higher odds for overweight and obesity in comparison to being a child of a mother with a college degree or higher, yet being a child of an elementary school educated mother did not. This could be explained with the argument that high school educated mothers are usually in a position to be full-time employed, but have less paid jobs in comparison to mothers with higher educational degrees and therefore neither have the funds nor time to prepare nutritious meals, afford high quality childcare or ensure participation in free-time sports clubs for their children ${ }^{36,37}$. This is supported by the finding that children of employed mothers had a higher risk of overweight and obesity than children of unemployed mothers. Interestingly, when stratified by sex, these predictors remained significant only for girls. The traditional role of women in Croatian society implies that female household members take care of family nutrition. In line with this, it could be argued that 
female children are expected to be more independent in relation to food intake, and could therefore receive less support from their time- and resource-constrained mothers than male children ${ }^{38}$.

Finally, the level of urbanization of the child's residence was not found to be a significant predictor of overweight and obesity in this study. There are studies that confirm this finding, which also did not find any difference in obesity between urban and rural children, but these are not very frequent ${ }^{39,40}$. Other studies from Europe and North America show that living in rural areas brings higher odds for being obese in comparison to living in urban areas ${ }^{41,42}$. However, this finding needs to be more thoroughly examined in the future, as our study had a rather small share of rural children due to the fact that it included only children from schools that are mostly located in urban or semi-urban areas, and not children from peripheral schools.

This study had several limitations. First, the sample was nationally, but not regionally representative. However, the large size of the sample gives us authority to make inferences based on acquired results. In addition, weights were calculated to post-stratify the sample by the 3 geographical regions. Second, in order to get a clearer picture of the origins of childhood obesity, it would be beneficial to have information on the parental weight status. Previous studies suggest that a child's weight status is positively associated with the weight status of parents ${ }^{43}$. Third, the response rate was $79.2 \%$, suggesting there might be a non-response bias at play. Yet, it is important to state that the response rate was similar to those from other European countries participating in this study and is, unfortunately, expected in a national study using anthropometric measurements $^{28}$. Fourth, we used BMI to assess the nutritional status of children, which is not the most accurate method of assessing body structure (muscle, bones, fat). Some of the differences in overweight and obesity prevalence observed in this study may therefore be the result of differing body structures.

In conclusion, the results of this study, using COSI methodology for the first time in Croatia, show that Croatia has one of the highest prevalence of childhood overweight and obesity among European countries and that this problem is more frequent among boys. Especially concerning is the high rate of overweight and obesity in boys living in the Adriatic region and the increased risk in girls with high-school educated and employed mothers. This information warrants urgent implementation of specifically directed health promotion measures. In addition, the results of this study show that it is essential to implement continuous, standardized surveillance of childhood obesity, such as the COSI study. Considering the very high prevalence established in this study, it is of utmost importance to set national and local time-bound targets for reduction in childhood overweight and obesity, as well as monitoring mechanisms. The national targets would have to be accompanied by a detailed action plan, which will require coordinated efforts from multiple governmental sectors and institutions contributing to policy development, implementation and workforce capacity strengthening.

\section{References}

1. World Health Organization [Internet]. Geneva: WHO; c2019 [cited 2019 May 30]. Childhood overweight and obesity. Available from: http://www.who.int/dietphysicalactivity/childhood/en/

2. World Health Organization [Internet]. Geneva: WHO; c2019 [cited 2019 May 30]. Obesity and overweight. Available from: https://www.who.int/news-room/fact-sheets/detail/obesityand-overweight

3. World Health Organization Regional Office for Europe [Internet]. COSI Factsheet - Childhood Obesity Surveillance Initiative Highlights 2015-17 [cited 2019 May 30]. Available from: http://www.euro.who.int/_data/assets/pdf_file/0006/ 372426/WH14_COSI_factsheets_v2.pdf?ua=1

4. Ahrens W, Pigeot I, Pohlabeln H, De Henauw S, Lissner L, Molnár D, et al. Prevalence of overweight and obesity in European children below the age of 10. Int J Obes. 2014;38(S2): 99-107. doi: 10.1038/ijo.2014.140.

5. Wijnhoven TM, van Raaij JM, Spinelli A, Rito AI, Hovengen R, Kunesova M, et al. WHO European Childhood Obesity Surveillance Initiative 2008: weight, height and body mass index in 6-9-year-old children. Pediatr Obes. 2013;8(2):79-97. doi: 10.1111/j.2047-6310.2012.00090.x.

6. Muthuri SK, Onywera VO, Tremblay MS, Broyles ST, Chaput JP, Fogelholm M, et al. Relationships between parental education and overweight with childhood overweight and physical activity in 9-11 year old children: results from a 12-country study. PLoS One. 2016;11(8):e0147746. doi: 10.1371/journal. pone. 0147746.

7. Zhang YX, Wang ZX, Zhao JS, Chu ZH. Prevalence of overweight and obesity among children and adolescents in Shandong, China: urban-rural disparity. J Trop Pediatr. 2016; 62(4):293-300. doi: 10.1093/tropej/fmw011.

8. Ruiz M, Goldblatt P, Morrison J, Porta D, Forastiere F, Hryhorczuk D, et al. Impact of low maternal education on early 
childhood overweight and obesity in Europe. Paediatr Perinat Epidemiol. 2016;30(3):274-84. doi: 10.1111/ppe.12285.

9. Taking Action on Childhood Obesity. World Health Organization; 2018.

10. Wijnhoven T, van Raaij J, Breda J. WHO European Childhood Obesity Surveillance Initiative - Implementation of round 1 (2007/2008) and round 2 (2009/2010). Copenhagen: World Health Organization Regional Office for Europe; 2014.

11. Childhood Obesity Surveillance Initiative (COSI) Protocol. Copenhagen: World Health Organization Regional Office for Europe; 2016.

12. Eurostat [Internet]. Regions in the European Union: nomenclature of territorial units for statistics NUTS 2013/EU-28 [cited 2018 Oct 1]. Available from: https://ec.europa.eu/eurostat/documents/3859598/6948381/KS-GQ-14-006-EN-N.pdf

13. Kern J, Strnad M, Čorić T, Vuletić S. Cardiovascular risk factors in Croatia: struggling to provide the evidence for developing policy recommendations. BMJ. 2005;331(7510):208-10. doi: $10.1136 /$ bmj.331.7510.208.

14. Croatian Bureau of Statistics [Internet]. The Model of the Differentiation of Urban, Rural and Semi-Urban Settlements in the Republic of Croatia [cited 2018 Oct 1]. Available from: https:// www.dzs.hr/Eng/Publication/metodologije/metod_67.pdf

15. De Onis M, Onyango AW, Borghi E, Siyam A, Nishida C, Siekmann J. Development of a WHO growth reference for school-aged children and adolescents. Bull World Health Organ. 2007;85(9):660-7. doi: 10.2471/BLT.07.043497.

16. Brug J, van Stralen MM, te Velde SJ, Chinapaw MJM, De Bourdeaudhuij I, Lien N, et al. Differences in weight status and energy-balance related behaviors among schoolchildren across Europe: the ENERGY-Project. PLoS One. 2012;7(4):e34742. doi: 10.1371/journal.pone.0034742.

17. Wijnhoven TM, van Raaij JM, Spinelli A, Starc G, Hassapidou M, Spiroski I, et al. WHO European Childhood Obesity Surveillance Initiative: body mass index and level of overweight among 6-9-year-old children from school year 2007/2008 to school year 2009/2010. BMC Public Health. 2014;14:806. doi: 10.1186/1471-2458-14-806.

18. Kontogianni MD, Vidra N, Farmaki AE, Koinaki S, Belogianni K, Sofrona S, et al. Adherence rates to the Mediterranean diet are low in a representative sample of Greek children and adolescents. J Nutr. 2008;138(10):1951-6. doi: 10.1093/ jn/138.10.1951.

19. Samdal O, Tynjälä J, Roberts C, Sallis JF, Villberg J, Wold B. Trends in vigorous physical activity and TV watching of adolescents from 1986 to 2002 in seven European countries. Eur J Public Health. 2007;17(3):242-8. doi: 10.1093/eurpub/ckl245.

20. Koebnick C, Getahun D, Smith N, Porter AH, Der-Sarkissian JK, Jacobsen SJ. Extreme childhood obesity is associated with increased risk for gastroesophageal reflux disease in a large population-based study. Int J Pediatr Obes. 2011;6(2-2):e25763. doi: 10.3109/17477166.2010.491118.

21. Van Emmerik NM, Renders CM, van de Veer M, van Buuren $\mathrm{S}$, van der Baan-Slootweg OH, Kist-van Holthe JE, et al. High cardiovascular risk in severely obese young children and adolescents. Arch Dis Child. 2012;97(9):818-21. doi: 10.1136/archdischild-2012-301877.

22. Rank M, Siegrist M, Wilks DC, Langhof H, Wolfarth B, Haller B, et al. The cardio-metabolic risk of moderate and severe obesity in children and adolescents. J Pediatr. 2013; 163(1):137-42. doi: 10.1016/j.jpeds.2013.01.020.

23. Song Y, Wang H-J, Ma J, Wang Z. Secular trends of obesity prevalence in urban Chinese children from 1985 to 2010: gender disparity. PLoS One. 2013;8(1):e53069. doi: 10.1371/journal.pone.0053069.

24. Govindan M, Gurm R, Mohan S, Kline-Rogers E, Corriveau $\mathrm{N}$, Goldberg $\mathrm{C}$, et al. Gender differences in physiologic markers and health behaviors associated with childhood obesity. Pediatrics. 2013;132(3):468-74. doi: 10.1542/peds.2012-2994.

25. Musić Milanović S. Demographic, behavioural and socio-economic determinants of obesity in Croatian adults [dissertation]. University of Zagreb School of Medicine; 2010.

26. Doko Jelinić J, Pucarin-Cvetković J, Nola IS, Senta A, Milošević M, Kern J. Regional differences in dietary habits of adult Croatian population. Coll Antropol. 2009;33(1):31-4.

27. Mistretta A, Marventano S, Antoci M, Cagnetti A, Giogianni G, Nolfo F, et al. Mediterranean diet adherence and body composition among southern Italian adolescents. Obes Res Clin Pract. 2017;11(2):215-26. doi: 10.1016/j.orcp.2016.05.007.

28. WHO European Childhood Obesity Surveillance Initiative: overweight and obesity among 6-9-year-old children. Report of the third round of data collection 2012-2013. Copenhagen: World Health Organization Regional Office for Europe; 2018.

29. Goldblatt PB, Moore ME, Stunkard AJ. Social factors in obesity. JAMA. 1965;192:1039-44. doi: 10.1001/jama.1965.030 80250017004

30. Stunkard A, d'Aquili E, Fox S, Filion RD. Influence of social class on obesity and thinness in children. JAMA. 1972;221 (6):579-84. doi: 10.1001/jama.1972.03200190023005.

31. Shrewsbury V,Wardle J. Socioeconomic status and adiposity in childhood: a systematic review of cross-sectional studies 1990 2005. Obesity. 2008;16(2):275-84. doi: 10.1038/oby.2007.35.

32. Science and Society Synergy Institute [Internet]. Vinković, D. Obrazovna struktura hrvatskih gradova i općina [cited 2018 Oct 1]. Available from: http://iszd.hr/2014/01/obrazovnastruktura-hrvatskih-opcina-i-gradova/?lang=hr (in Croatian)

33. Croatian Bureau of Statistics [Internet]. Statistical Yearbook of the Republic of Croatia [cited 2018 Oct 1]. Available from: http://www.dzs.hr/Hrv_Eng/ljetopis/2011/SLJH2011.pdf

34. Bammann K, Gwozdz W, Lanfer A, Barba G, De Henauw S, Eiben G. Socioeconomic factors and childhood overweight in Europe: results from the multi-centre IDEFICS study. Pediatr Obes. 2013;8(1):1-12. doi: 10.1111/j.2047-6310.2012.00075.x.

35. Baughcum AE, Chamberlin LA, Deeks CM, Powers SW, Whitaker RC. Maternal perceptions of overweight preschool children. Pediatrics. 2000;106(6):1380-6. doi: 10.1542/peds. 106.6.1380. 
36. Brown JE, Broom DH, Nicholson JM, Bittman M. Do working mothers raise couch potato kids? Maternal employment and children's lifestyle behaviours and weight in early childhood. Soc Sci Med. 2010:70(11):1816-24. doi: 10.1016/j.socscimed.2010.01.040.

37. Cawley J, Liu F. Maternal employment and childhood obesity: a search for mechanisms in time use data. Econ Hum Biol. 2012;10(4):352-64. doi: 10.1016/j.ehb.2012.04.009.

38. Leinert Novosel S. Social status of women in Croatia: woman and Family 1999-2016. Politička misao. 2018;55(1):53-72. doi: 10.20901/pm.55.1.04.

39. Bilić-Kirin V, Gmajnić R, Burazin J, Miličić V, Buljan V, Ivanko M. Association between socioeconomic status and obesity in children. Coll Antropol. 2014;38(2):553-8.

40. Cesani MF, Garraza M, Sanchís MLB, Luis MA, Torres MF, Quintero FA, et al. A comparative study on nutritional status and body composition of urban and rural schoolchildren from Brandsen District (Argentina). PLoS One. 2013;8(1):e52792. doi: 10.1371/journal.pone.0052792.

41. Magnusson M, Sørensen TI, Olafsdottir S, Lehtinen-Jacks S, Holmen TL, Heitmann BL, et al. Social inequalities in obesity persist in the Nordic region despite its relative affluence and equity. Curr Obes Rep. 2014;3(1):1-15. doi: 10.1007/s13679013-0087-2.

42. Johnson JA, Johnson AM. Urban-rural differences in childhood and adolescent obesity in the United States: a systematic review and meta-analysis. Child Obes. 2015;11(3):233-41. doi: 10.1089/chi.2014.0085.

43. Birbilis M, Moschonis G, Mougios V, Manios Y. Obesity in adolescence is associated with perinatal risk factors, parental BMI and sociodemographic characteristics. Eur J Clin Nutr. 2013;67(1):115-21. doi: 10.1038/ejcn.2012.176.

Sažetak

\section{REGIONALNE I SOCIODEMOGRAFSKE ODREDNICE UČESTALOSTI PREKOMJERNE TJELESNE MASE I DEBLJINE U DJECE U DOBI OD 7-9 GODINA U HRVATSKOJ}

\section{S. Musić Milanovic, M. Lang Morović, D. Bukal, H. Križan, M. Buoncristiano i J. Breda}

Cilj ovoga istraživanja bio je utvrditi učestalost i analizirati odrednice prekomjerne tjelesne mase i debljine kod školske djece u dobi od 7-9 godina u Hrvatskoj u odnosu na sociodemografske čimbenike. U istraživanju su korišteni podaci prikupljeni u sklopu istraživanja SZO Europa "Europska inicijativa praćenja debljine u djece, Hrvatska 2015./2016.”. Uzorak u ovom istraživanju bio je nacionalno reprezentativan. Antropometrijska mjerenja 5591 djeteta, 2811 dječaka i 2780 djevojčica, provedena su standardiziranom opremom kroz 8 tjedana. Proučavane varijable bili su antropometrijski i demografski podaci djece, obrazovanje i zaposlenost majki. Prema rezultatima, učestalost prekomjerne tjelesne mase i debljine u hrvatske djece $u$ dobi od 7-9 godina iznosi 35,9\%. Učestalost prekomjerne tjelesne mase i debljine veća je kod dječaka nego kod djevojčica, a izrazito je velika kod dječaka iz jadranske regije (42,1\%). Rizik za prekomjernu tjelesnu masu i debljinu veći je za dječake koji žive u jadranskoj regiji (ORadj=1,33; 95\% CI 1,03-1,71) i djevojčice čije majke imaju srednjoškolsko obrazovanje (ORadj=1,36; 95\% CI 1,11-1,66). Djevojčice čije su majke nezaposlene imaju manji rizik od prekomjerne tjelesne mase i debljine (ORadj=0,73; 95\% CI 0,58-0,92). Uočena učestalost prekomjerne tjelesne mase i debljine zahtijeva vremenski ograničene, nacionalne i lokalne, ciljeve za smanjenje debljine kod djece, praćene detaljnim akcijskim planovima i mehanizmima praćenja.

Ključne riječi: Učestalost; Prekomjerna tjelesna masa; Debljina; Djeca; Hrvatska 